\title{
CHEMICAL COMPOSITION OF THE LEAF OIL OF PEPEROMIA HERNANDIIFOLIA (PIPERACEAE) FROM COSTA RICA
}

\author{
José F. Cicció \\ Centro de Investigaciones en Productos Naturales (CIPRONA) and Escuela de Química, Universidad de Costa Rica, \\ 2060 San José, Costa Rica. jfciccio@equi.ucr.ac.cr
}

\begin{abstract}
The composition of the essential oil from leaves of Peperomia hernandiifolia (Piperaceae) from Costa Rica was analyzed by capillary GC/MS. Eight compounds were identified corresponding to about $99 \%$ of the oil. The oil was constituted almost exclusively by fatty acid derivatives. The mayor components were decanal (85.0\%) and decanoic acid (12.6\%).

Resumen. Se estudió la composición del aceite esencial de las hojas de Peperomia hernandiifolia (Piperaceae) de Costa Rica, mediante la técnica de cromatografía de gases capilar y espectrometría de masas (GC/MS). Se identificaron ocho compuestos que representan cerca de $99 \%$ del aceite obtenido. El aceite está constituido casi exclusivamente por derivados de ácidos grasos. El decanal (85.0\%) es el constituyente mayoritario, seguido por el ácido decanoico (12.6\%).
\end{abstract}

Key Words / Palabras Clave: Piperaceae, Peperomia hernandiifolia, leaf essential oil composition, GC/MS, fatty acid derivatives, decanal, decanoic acid.

\section{INTRODUCTION}

The genus Peperomia Ruiz \& Pav. belongs to the Piperaceae family (some authors put the genus in the Peperomiaceae family). It is constituted mainly by herbs growing as epiphytes of tropical and subtropical regions. Most of this genus occurs in Central and Northern South America. In Costa Rica, the genus is best represented in the evergreen rainforest habitats of the Caribbean slope and the central highlands with over sixty species (Burger 1971).

In Middle America and South America (Morton 1981, Duke \& Vásquez 1994) some species of the genus Peperomia are used traditionally to treat various ailments: colds and coughs, influenza, fever and bronchitis, as a diuretic, sudorific and vulnerary, to relieve headaches, for indigestion and stomach pains, and also for snakebites. Some dried plants are smoked or, fresh plants are extracted with water, to relieve asthma. Several species are used as ornamentals.

Peperomia hernandiifolia (Vahl) A.Dietrich is distributed from Mexico and the West Indies to South America. This is a terrestrial or epiphytic climbing succulent herb, rooting at most nodes. The leaves are alternate and peltate, broadly ovate, tapering to short acuminate apex, rounded or subcordate at the base. The inflorescences are leaf-opposed, terminal and solitary, up to about $25 \mathrm{~cm}$ long (Burger 1971). When leaves are crushed they give off a scent reminiscent of coriander due to an essential oil of unknown composition.

The chemical composition of the volatile oils of some species belonging to this genus has been the subject of several studies (de Díaz et al. 1988, Bessiere et al. 1994, da Silva et al. 1999, Moreira et al. 1999, dos Santos et al. 2001).

To the best of my knowledge nothing has been reported concerning the composition of the essential oil of this plant.

\section{MATERIALS AND METHODS}

Plant Material: Leaves of Peperomia hernandiifolia were collected in December 2000, near Pacayas, Cartago (Costa Rica). A voucher specimen was deposited at the Herbarium of the University of Costa Rica (herbarium number USJ-77432).

Oil Isolation: Fresh leaves were subjected to hydrodistillation for 3 hours using a modified Clevenger-type apparatus. The distilled oil was collected and dried over anhydrous sodium sulfate and stored in a freezer at $0^{\circ}-10^{\circ} \mathrm{C}$.

General Analytical Procedures: The GC/MS analyses were performed using a Shimadzu GCMSQP5050 apparatus and CLASS 5000 software with 
Wiley 138 computer database. The data were obtained on a $5 \%$ phenyl methyl silicone fused silica capillary column (30 m x $0.25 \mathrm{~mm}$, film thickness $0.25 \mu \mathrm{m}$ ). Operation conditions were: carrier gas $\mathrm{He}$, flow 1.0 $\mathrm{mL} / \mathrm{min}$; oven temperature program $60^{\circ}-240^{\circ} \mathrm{C}$ at $2^{\circ} \mathrm{C} / \mathrm{min}$; sample injection port temperature $250^{\circ} \mathrm{C}$; detector temperature $260^{\circ} \mathrm{C}$; ionization voltage: 70 $\mathrm{eV}$; ionization current $60 \mu \mathrm{A}$; scanning speed $0.5 \mathrm{sec}$ over 38-400 amu range; split 1:70.

Identification: Identification of the components of the oil was performed using the retention indices on a DB-5 column, and by comparison of their mass spectra with those published in the literature (Stenhagen 1974, Adams 1995) or those of our own database.

\section{RESULTS AND DISCUSSION}

The composition of the oil is summarized in Table 1 . Decanal was found to be the major constituent of the oil $(85.0 \%)$ with decanoic acid $(12.6 \%)$ as the second compound in quantity. The other constituents with the exception of $(E)$ - $\beta$-ocimene (in traces) are fatty acid

Table 1. Chemical composition of the leaf oil of Peperomia hernandiifolia from Costa Rica.

\begin{tabular}{|lcc|}
\hline Compound $^{\mathbf{a}}$ & Percentage & $\begin{array}{c}\text { Identification } \\
\text { Method }^{\mathbf{c}}\end{array}$ \\
\hline nonane & 0.2 & $1,2,3$ \\
1-octen-3-ol & 0.9 & 1,2 \\
3-octanol & 0.3 & $1,2,3$ \\
$(E)$ - $\beta$-ocimene & $\mathrm{b}^{\mathrm{b}}$ & 1,2 \\
nonanal & 0.1 & 1,2 \\
decanal & 85.0 & 1,2 \\
decanoic acid & 12.6 & $1,2,3$ \\
dodecanoic acid & 0.1 & $1,2,3$ \\
\hline
\end{tabular}

aCompounds are listed by elution order in a 5\% phenyl methyl silicone column.

$\mathrm{b}_{\mathrm{t}}=$ Trace $(<0.05 \%)$

cMethod: $1=$ Retention Indices on 5\% phenyl methyl silicone column; $2=$ MS spectra; $3=$ standard.

The chemical composition of the oils of several Peperomia species from South America (de Díaz et al. 1988, Bessiere et al. 1994, da Silva et al. 1999, Moreira et al. 1999, dos Santos et al. 2001) have been previously reported. From these results, at least two different types of oils can be distinguished in this genus:

(a) Oils containing arylpropanoid compounds (like apiol, elemicin and safrole)

(b) Oils rich in terpenoids (with monoterpenoids like pinenes, limonene and camphor; and with sesquiterpenoids like $\beta$-caryophyllene, germacrene $\mathrm{D}$, hinesol and $\alpha$-eudesmol).

The results obtained in our analysis showed that the oil of Peperomia hernandiifolia represents a different chemical type of essential oil within this genus of plants. This oil belongs to a new third group of oils composed mainly of fatty acid derivatives.

The occurrence of aldehydes and alcohols in this Peperomia oil, like in coriander (Coriandrum sativum L., Apiaceae) leaf oil (Potter 1996), is presumably responsible for the characteristic flavour of the analyzed plant.
AcknOwledgments. The author is grateful to Vicerrectoría de Investigación, Universidad de Costa Rica (Project 809-93-600) for financial support. To L.J. Poveda (Escuela de Ciencias Ambientales, Universidad Nacional) for the identification of the plant. To L. Hernández (CIPRONA) for her technical assistance and to N.R. Farnsworth (College of Pharmacy, University of Illinois at Chicago, USA) for his help to access the NAPRALERT database.

\section{Literature Cited}

Adams, R.P. 1995. Identification of Essential Oil Components by Gas Chromatography / Mass Spectroscopy. Allured Publ., Illinois.

Bessiere, J.M., C. Menut, G. Lamaty \& H. Joseph. 1994. Variations in the volatile constituents of Peperomia rotundifolia Schlecht. \& Cham. grown on different host-trees in Guadeloupe. Flavour Fragr. J. 9: 131-133.

Burger, W. 1971. Family \# 41. Piperaceae. In: Burger, W. (ed.). Flora Costaricensis. Fieldiana, Bot. 35: 5218.

da Silva, M.H.L., M.D.G.B. Zoghbi, E.H.A. Andrade \& J.G.S. Maia. 1999. The essential oil of Peperomia 
pellucida Kunth and $P$. circinnata Link var. circinnata. Flavour Fragr. J. 14: 312-314.

de Díaz, A.M.P., P.P. Díaz \& H. Cardoso. 1988. Volatile constituents of Peperomia subspathulata. Planta Med. 54: 92-93.

dos Santos, P.R.D., D.L. Moreira, E.F. Guimarães \& M.A.C. Kaplan. 2001. Essential oil analysis of 10 Piperaceae species from the Brazilian Atlantic forest. Phytochemistry 58: 547-551.

Duke, J.A. \& R. Vásquez. 1994. Amazonian Ethnobotanical Dictionary. CRC Press, Florida. 215 p.

McLafferty, F. W. 1993. Registry of Mass Spectral Data. John Wiley, New York.
Moreira, D.L., P.O. de Souza, M.A.C. Kaplan \& E.F. Guimarães. 1999. Essential oil analysis of four Peperomia species (Piperaceae). Acta Hort. (ISHS) 500: 65-70.

[http://www.actahort.org/books/500/500_7.htm] Morton, J.F. 1981. Atlas of Medicinal Plants of Middle America. Bahamas to Yucatan. C.C. Thomas, Illinois.

Potter, T.L. 1996. Essential oil composition of cilantro. J. Agric. Food Chem. 44: 1824-1826.

Stenhagen, E., S. Abrahamsson \& F.W. MacLafferty (eds.). 1974. Registry of Mass Spectral Data. J. Wiley, New York. 